\title{
KONTRIBUSI PERSEPSI SISWA MENGENAI PERAN ORANG TUA DALAM PENDIDIKAN TERHADAP MOTIVASI BELAJAR SISWA PADA MATA PELAJARAN PRODUKTIF
}

\author{
Hadi Heriawan $^{1}$, Iwa Kuntadi ${ }^{2}$, Haryadi $^{3}$ \\ Departemen Pendidikan Teknik Mesin, FPTK UPI \\ Jl. Dr. Setiabudi No. 207 Bandung 40154 \\ hadi.heriawan@yahoo.com
}

\begin{abstract}
ABSTRAK
Penelitian ini bertujuan untuk mengetahui seberapa besar kontribusi tingkat persepsi siswa tentang peran orang tua dalam pendidikan terhadap motivasi belajar siswa pada mata pelajaran produktif pada siswa kelas XI TKR di SMK Negeri 6 Bandung. Metode yang digunakan pada penelitian ini adalah assosiatif kausal dengan jumlah responden 45 siswa. Teknik pengumpulan data yang dilakukan untuk kedua variabel, yaitu dengan menggunakan angket. Hasil penelitian menunjukan tingkat persepsi siswa tentang peran orang tua dalam pendidikan termasuk dalam kategori cukup, motivasi belajar siswa pada mata pelajaran produktif dalam kategori baik, tingkat persepsi siswa tentang peran orang tua dalam pendidikan berkontribusi terhadap motivasi belajar siswa sebesar 23,04\% yaitu pada kriteria sedang. Terdapat kontribusi yang positif dan signifikan antara tingkat persepsi siswa tentang peran orang tua dalam pendidikan terhadap motivasi belajar siswa pada mata pelajaran produktif.
\end{abstract}

Kata kunci: persepsi siswa, peran orang tua, motivasi belajar

\section{PENDAHULUAN}

Pendidikan merupakan usaha sadar dan terencana untuk mewujudkan suasana belajar dan proses pembelajaran agar siswa secara aktif mengembangkan potensi dirinya. Pendidikan seorang siswa erat kaitannya dengan proses belajar, dimana dalam proses belajar motivasi sangat diperlukan karena motivasi sangat menentukan tingkat berhasil atau gagalnya perbuatan belajar siswa. Belajar tanpa adanya motivasi kiranya akan sangat sulit untuk berhasil (Hamalik, 2011). Seseorang yang tidak mempunyai motivasi dalam belajar, tidak akan mungkin melakukan aktivitas belajar.

Motivasi atau dorongan itu bisa datang dari luar maupun dari dalam diri, sebenarnya pada dasarnya semua motivasi itu datang dari dalam diri. Faktor luar hanyalah pemicu munculnya motivasi tersebut. Menurut Dalyono (2005), motivasi yang berasal dari dalam diri (intrinsik) yaitu dorongan yang datang dari hati sanubari, umumnya karena kesadaran akan pentingnya

\footnotetext{
${ }^{1}$ Mahasiswa Departemen Pendidikan Teknik Mesin FPTK UPI

${ }^{2}$ Dosen Departemen Pendidikan Teknik Mesin FPTK UPI

${ }^{3}$ Dosen Departemen Pendidikan Teknik Mesin FPTK UPI
} 
sesuatu dan motivasi yang berasal dari luar (ekstrinsik) yaitu dorongan yang datang dari luar diri (lingkungan), seperti dari orang tua, guru, teman-teman dan anggota masyarakat.

Orang tua menjadi lingkungan pertama dan utama dalam memberikan motivasi belajar kepada anak, karena dalam keluarga inilah anak mendapat pendidikan dan bimbingan, selain itu dikatakan bahwa lingkungan yang utama karena sebagian besar dari kehidupan anak adalah di dalam keluarga.

Orang tua mempunyai fungsi tidak hanya terbatas selaku penerus keturunan saja, tetapi dalam bidang pendidikan, orang tua merupakan sumber pendidikan utama, karena segala pengetahuan dan kecerdasan intelektual anak diperoleh dari orang tua sendiri (Gunarsyah,1995). Sehingga, pendidikan yang paling banyak diterima oleh anak datangnya dari orang tua, oleh karena itu peran orang tua salah satu yang sangat penting dalam meningkatkan mutu pendidikan di Indonesia. Mutu pendidikan di Indonesia ini rendah dikarenakan sangat minimnya peran serta masyarakat, khususnya orang tua siswa dalam penyelenggaraan pendidikan (Nursito, 2002).

Penyelenggaraan pendidikan pada pendidikan formal terdiri dari: Pendidikan dasar (SD), Pendidikan menengah (SMP, SMA, SMK) dan Pendidikan tinggi (Diploma, Sarjana), untuk siswa kelas IX SMP (Sekolah Menengah Pertama) mereka harus memikirkan apakah mereka akan melanjutkan ke SMA atau melanjutkan ke SMK. Orang tua yang memilih anaknya masuk SMK bertujuan agar setelah lulus sekolahanaknya bisa langsung bekerja. Oleh karena itu, orang tua akan lebih memfokuskan dalam hal fasilitas atau materi walaupun misalnya kemampuan ekonominya rendah. Semua itu agar anaknya dapat bersekolah tanpa ada hambatan, sehingga setelah lulus sekolah siswa dengan segera dapat mencari pekerjaan. Kebutuhan anak tidak hanya berupa fasilitas dan materi, tetapi juga perhatian, kasih sayang, pengarahan, perlindungan, dan pengertian dari orang tua.

Kondisi ini mengakibatkan siswa yang masih memerlukan perhatian dan kasih sayang orang tua menjadi terabaikan. Masalah pendidikan siswa yang merupakan tanggung jawab bersama antara orang tua, sekolah, dan lingkungan masyarakat menjadi pincang, karena peranan orang tua menjadi berkurang. Orang tua terlalu mempercayakan pendidikan anak ini kepada sekolah, sedangkan waktu anak di sekolah sangat terbatas. Orang tua beranggapan bahwa mereka cukup memberikan fasilitas dan kebutuhan materi. Urusan di luar hal-hal tersebut dapat diselesaikan anak bersama gurunya di sekolah. Kondisi ini berdampak pada menurunnya semangat siswa, terutama pada kegiatan belajarnya. 
Siswa merasa tidak mendapatkan dorongan yang diinginkan dari orang tuanya. Penyebabnya orang tua kurang memberikan perhatian pada pendidikan yang sedang dilakukan siswa, sehingga dapat menghambat proses belajar siswa, karena tanpa adanya peran orang tua dalam proses belajar, maka motivasi belajar siswa akan berkurang, karena pembelajaran yang tinggi motivasinya, umumnya tinggi pula perolehan belajarnya, sebaliknya pembelajaran yang rendah motivasinya, rendah pula perolehan belajarnya (Kurniadi, 2001).

Akibat dari hasil belajar yang diperoleh rendah, maka akhirnya sumber daya manusia yang berkualitas pun menjadi rendah, karena Sumber Daya Manusia (SDM) yang berkualitas merupakan salah satu modal yang penting dalam pembangunan suatu bangsa salah satunya melalui pendidikan, apabila hal ini terus berlanjut akibatnya tujuan pendidikan di Indonesia sulit untuk tercapai.

Permasalahan yang peneliti temukan saat mengikuti PPL (Program Pengalaman Lapangan) di SMK Negeri 6 Bandung Tahun Ajaran 2012/2013, bahwa motivasi belajar siswa bisa dikatakan masih tergolong rendah. Terlihat dari jam masuk pagi semua mata pelajaran produktif yaitu pukul 07.00, tetapi siswa terlambat masuk kelas, bahkan banyak siswa sudah dilingkungan sekolah tetapi tidak ada dikelas.

Hasil pengamatan yang peneliti lakukan selama PPL di SMKN 6 Bandung. Siswa-siswi yang sudah berada dikelas hanya tujuh sampai delapan siswa dari jumlah keseluruhannya 37 siswa, jadi 93\% siswa-siswi terlambat masuk kelas. Penulis bertanya kepada beberapa siswa yang berada dikelas dan ditambah pernyataan siswa-siswi yang terlambat masuk jam pelajaran.

Siswa-siswi yang terlambat sedang sarapan dikantin sekolah, apabila siswa tidak mengkonsumsi makanan sebelum belajar, maka siswa akan kekurangan gizi. Kekurangan zat gizi pada masa remaja akan berdampak pada aktifitas siswa di sekolah antara lain, sluggishness (lesu), mudah letih/lelah, hambatan pertumbuhan, kurang gizi pada masa dewasa, dan penurunan prestasi disekolah. Permasalahan selanjutnya yaitu ditemukannya siswa yang mengerjakan pekerjaan rumah disekolah pada mata pelajaran produktif, baik pada saat jam kosong atau ada jam pelajarannya, padahal seharusnya siswa mengerjakan PR dirumah. Pada jam masuk pagi pelajaran produktif sebagian besar siswa-siswi terlambat masuk kelas dikarenakan sarapan dikantin sekolah, hal tersebut berdampak pada jam belajar menjadi berkurang.

Kedua permasalahan tersebut mengindikasikan kurangnya peran orang tua terhadap kelangsungan proses belajar siswa terutama dalam komunikasi yang menyebabkan motivasi 
belajar siswa rendah. Suasana komunikasi orang tua di rumah mempunyai peranan penting dalam menentukan kegiatan belajar anak atau siswa baik di rumah ataupun di sekolah. Orang tua harus menjadikan rumah sebagai wadah berkomunikasi secara intens dengan anaknya yang berhubungan dengan kegiatan belajar anak di rumah, dan di luar rumah serta pemenuhan kebutuhan belajar anak (Subroto,1997). Orang tua yang kurang memperhatikan kemajuan dan kebutuhan pendidikan anak, dapat menyebabkan anaknya kurang berhasil dalam belajarnya.

Persepsi merupakan suatu proses yang didahului oleh proses penginderaan, yaitu proses diterimanya stimulus oleh individu melalui alat indera dan juga disebut proses sensoris, namun proses itu tidak berhenti begitu saja, melainkan stimulus tersebut diteruskan dan proses selanjutnya merupakan proses persepsi, karena itu proses persepsi tidak lepas dari proses penginderaan, dan proses penginderaan merupakan proses pendahulu dari proses persepsi.

Proses penginderaan akan berlangsung setiap saat, pada waktu individu menerima stimulus melalui alat indera, yaitu melalui mata sebagai alat penglihatan, telinga sebagai alat pendengar, hidung sebagai alat penciuman, lidah sebagai alat pengecap, kulit pada telapak tangan sebagai alat peraba yang kesemuanya merupakan alat indera yang digunakan untuk menerima stimulus dari luar individu. Alat indera tersebut merupakan alat penghubung antara individu dengan dunia luarnya (Walgito, 2010).

Persepsi merupakan proses yang integrated dalam diri individu terhadap stimulus yang diterimanya, dengan demikian dapat disimpulkan bahwa persepsi itu merupakan pengorganisasian, interprestasian terhadap stimulus yang diinderanya sehingga merupakan sesuatu yang berarti, dan merupakan respon integrated dalam diri individu (Walgito, 2010). Alam penginderaan orang akan mengaitkan dengan stimulus, sedangkan dalam persepsi orang akan mengaitkan dengan objek, dalam persepsi stimulus dapat datang dari luar, tetapi juga dapat datang dalam diri individu sendiri, namun demikian sebagian besar stimulus datang dari luar individu yang bersangkutan. Sekalipun persepsi dapat dengan alat indera yang ada pada diri individu, tetapi sebagian besar persepsi melalui alat indera penglihatan, karena itulah banyak penelitian mengenai persepsi adalah persepsi yang berkaitan dengan alat penglihatan.

Persepsi yang merupakan aktivitas integrated dalam diri individu, maka apa yang ada dalam diri individu akan ikut akif dalam persepsi. Berdasarkan hal tersebut maka dalam persepsi dapat dikemukakan karena perasaan, kemampuan berpikir, pengalaman-pengalaman individu tidak sama, maka dalam mempersepsi sesuatu stimulus. Hasil persepsi mungkin akan berbeda 
antara individu satu dengan individu lain, karena tiap individu memiliki pola pikir yang berbedabeda.

Peran orang tua dalam pendidikan sangat menentukan keberhasilan pendidikan anakanaknya. Orang tua dalam pendidikan memiliki beberapa peran yaitu: sebagai fasilitator, sebagai pembimbing dan pendorong (motivator), (Slameto 2010). Motif dapat dikatakan sebagai daya penggerak dari dalam dan di dalam subjek untuk melakukan aktivitas-aktivitas tertentu demi mencapai suatu tujuan. Motivasi adalah perubahan energi dalam diri seseorang yang ditandai dengan munculnya feeling dan didahului dengan tanggapan terhadap adanya tujuan (Sardiman, 2010).

Berdasarkan penjelasan di atas, dikatakan bahwa motivasi itu sebagai sesuatu yang kompleks. Motivasi akan menyebabkan terjadinya suatu perubahan energi yang ada pada diri manusia, sehingga akan saling berhubungan dengan persoalan gejala kejiwaan, perasaan dan juga emosi. Kemudian bertindak atau melakukan sesuatu, semua ini didorong karena adanya tujuan, kebutuhan atau keinginan, dalam kegiatan belajar mengajar. Apabila ada seseorang siswa misalnya tidak berbuat sesuatu yang seharusnya dikerjakan, maka perlu diselidiki sebabsebabnya.

Belajar akan lebih baik jika selalu disertai dengan motivasi yang sungguh-sungguh, maka tidaklah mengherankan apabila ada seseorang yang mampu mencapai prestasi sesuai dengan yang diharapkan. Pada proses belajar mengajar, motivasi mempunyai peran dan fungsi yang sangat penting. Terdapat tiga fungsi motivasi dalam belajar yaitu: mendorong manusia untuk bertindak atau berbuat, menentukan arah perbuatan, yakni ke arah perbuatan suatu tujuan dan cita-cita, dan menyeleksi perbuatan, menentukan perbuatan mana yang harus dilakukan, yang sesuai guna mencapai tujuan (Sardiman, 2010).

\section{METODE PENELITIAN}

Metode penelitian yang digunakan adalah assosiatif kausal. Lokasi pada penelitian ini bertempat di Sekolah Menengah Kejuruan Negeri 6 Bandung yang beralamat di Jl. Soekarno-

Hatta, Riung Bandung 40295. Objek pada penelitian ini ditujukan kepada siswa kelas XI Program Keahlian Teknik Kendaraan Ringan. Populasi dalam penelitian ini adalah seluruh siswa angkatan 2013/2014 program studi Teknik Kendaraan Ringan, kelas XI semester 1 SMK Negeri 6 Bandung. Sampel yang diambil dalam penelitian ini menggunkan teknik sampel Probably 
Sampling Simple Random Sampling, yaitu teknik pengambilan sampel yang memberikan peluang yang sama bagi setiap unsur (anggota), hal ini dilakukan dengan cara mengambil anggota sampel dari populasi yang dilakukan secara acak.

Daftar hadir siswa angkatan 2013/2014 program studi Teknik Kendaraan Ringan, kelas X semester 1 SMK Negeri 6 Bandung, bahwa populasinya terdiri dari 224 orang. Data dianalisis dengan langkah-langkah, sebagai berikut: pengujian validitas dan reliabilitas instrumen, pengolahan dan analisi data penelitian, pembahasan hasil penelitian.

\section{HASIL PENELITIAN}

Hasil pengujian validitas angket yang diuji coba ke-37 siswa-siswi SMKN 6 diperoleh 25 item yang valid untuk variabel $\mathrm{X}$, sedangkan untuk variabel $\mathrm{Y}$ diperoleh 30 item yang valid, untuk item yang tidak valid tidak dipergunakan, kemudian angket disebarkan untuk mendapatkan data penelitian.

Hasil perhitungan uji reliabilitas, diperoleh bahwa hasil angket yang dibuat pada variabel X memiliki tingkat reliabilitas 0,874 dan variabel $\mathrm{Y}=0,875$. Hasil tersebut dapat dikategorikan dalam interprestasi yang sangat tinggi, artinya instrumen penelitian tersebut reliabel untuk digunakan sebagai angket penelitian. Instrumen penelitian berupa angket, kemudian dikumpulkan dari responden dan hasilnya diberi skor untuk setiap item seluruh reponden, serta dihitung jumlah skornya untuk masing-masing variabel.

Data yang diperoleh dari hasil pengumpulan data dengan menggunakan teknik angket dan teknik dokumentasi kemudian diolah menggunakan analisis statistik yang selanjutnya analisis data digunakan untuk menguji hipotesis. Berdasarkan tingkat kriterium variabel $\mathrm{X}$ diperoleh sebesar 67,8 \% atau pada taraf kriterium cukup rendah. Berdasarkan tingkat kriterium variabel Y diperoleh sebesar 76,64\% atau pada taraf kriterium baik. Hasil perhitungan chi kuadrat diperoleh

$\chi^{2}=1,06$ diperoleh $p-v=0,1272$, ternyata $p-v>0,05$ maka dapat dikatakan bahwa penyebaran skor variabel X berdistribusi normal pada taraf kesalahan $\alpha=0,05$.

Hasil perhitungan chi kuadrat diperoleh $\chi^{2}=5,6$ diperoleh $p-v=0,0725$, ternyata $p-v>0,05$ maka dapat dikatakan bahwa penyebaran skor variabel Y berdistribusi normal pada taraf kesalahan $\alpha=0,05$. Hasil perhitungan homogenitas chi kuadrat diperoleh $\chi^{2}=6,56$. Hasil perhitungan chi kuadrat tersebut, selanjutnya dikonsultasikan ke dalam Tabel $\chi^{2}$, maka didapat 


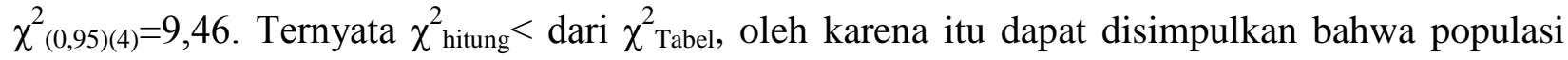
pada variabel $X$ homogen pada tingkat kepercayaan 95\% dengan derajat kebebasan $\mathrm{dk}=4$.

Hasil perhitungan chi kuadrat homogenitas diperoleh $\chi^{2}=1,62$. Hasil perhitungan chi kuadrat tersebut, selanjutnya dikonsultasikan ke dalam Tabel $\chi 2$, maka didapat $\chi 2_{(0,95)(4)}=9,46$. Ternyata $\chi_{\text {hitung }}^{2}<$ dari $\chi_{\text {Tabel }}^{2}$, oleh karena itu dapat disimpulkan bahwa populasi pada variabel $\mathrm{X}$ homogen pada tingkat kepercayaan $95 \%$ dengan derajat kebebasan $\mathrm{dk}=4$. Hasil perhitungan persamaan regresi linier variabel X dan variabel Y diperoleh harga koefisien a sebesar 26,19 dan koefisien b sebesar 0,48 sehingga diperoleh persamaan regresi $Y=26,19+0,48$.X.

Perhitungan uji korelasi dalam penelitian ini menggunakan rumus $\mathrm{r}$ product moment, diperoleh harga $r$ sebesar 0,48 . Selanjutnya harga koefisien korelasi ini di interprestasikan pada indeks korelasi termasuk dalam korelasi/hubungan (cukup rendah), dan mempunyai arah hubungan yang positif.

Pengujian korelasi ini dimaksudkan untuk melihat berarti atau tidaknya hubungan yang ada antara variabel $\mathrm{X}$ dan $\mathrm{Y}$. Hasil perhitungan diperoleh $\mathrm{t}_{\text {hitung }}=3,59$; dan $\mathrm{t}_{\text {Tabel }} \mathrm{untuk} \mathrm{dk}=43$ pada taraf kepercayaan 95\% diperoleh $\mathrm{t}_{\text {Tabel }}=1,678$; maka 3,59>1,678; sehingga dapat disimpulkan korelasi berarti (signifikan). Hasil perhitungan diperoleh harga koefisien determinasi sebesar 23,04\%, sehingga dapat disimpulkan bahwa variabel X (peran orang tua) memberikan kontribusi terhadap variabel Y (Motivasi belajar siswa) sebesar 23,04\% pada taraf kriteria cukup rendah.

Berdasarkan kriteria pengujian hipotesis, $\mathrm{p}-\mathrm{v}=-0,08<0,05$; ternyata $p-v<0,05$; diperoleh terdapat kontribusi yang positif dan signifikan antara tingkat persepsi siswa tentang peran orang tua dalam pendidikan terhadap motivasi belajar siswa pada mata pelajaran produktif.

\section{PEMBAHASAN}

Pembahasan hasil penelitian ini dimaksudkan untuk memberikan penjelasan tentang hasil penelitian yang dilakukan. Berdasarkan hasil penelitian yang dilakukan dengan menggunakan statistik parametrik dapat dijelaskan bahwa, terdapat kontribusi yang positif dan signifikan antara persepsi siswa tentang peran orang tua dalam pendidikan terhadap motivasi belajar siswa pada mata pelajaran produktif di SMKN 6 Bandung. Peran orang tua dalam penelitian ini, termasuk 
kedalam faktor eksternal yang mendukung kegiatan belajar, serta ikut andil dalam motivasi belajar siswa pada mata pelajaran produktif di SMKN 6 Bandung.

Berdasarkan penilaian tingkat kriterium persepsi siswa tentang peran orang tua dalam pendidikan termasuk kedalam kategori kriterium cukup rendah, jadi penilaian menurut siswa tentang peran orang tuanya secara keseluruhan pada penelitian ini dalam kategori cukup rendah. Berdasarkan penilaian tingkat kriterium motivasi belajar pada mata pelajaran produktif termasuk kedalam kategori kriterium baik, jadi motivasi belajar siswa pada mata pelajaran produktif dapat disimpulkan dalam kategori baik. Hasil dari uji normalitas variabel tingkat persepsi siswa tentang peran orang tua dan variabel motivasi belajar siswa menunjukan bahwa sebaran data berdistribusi normal, dan dari hasil uji homogenitas kedua variabel dinyatakan homogen, sehingga dapat ditarik kesimpulan bahwa teknik statistik yang digunakan adalah statistik parametrik.

Hasil perhitungan analisis regresi, diperoleh nilai persamaan regresi $Y=26,19+0,48 . X$, dan dapat diartikan bahwa semakin tinggi variabel $X$ (tingkat persepsi siswa tentang peran orang tua), maka semakin meningkat/tinggi variabel Y (motivasi belajar siswa). Dapat disimpulkan, siswa membutuhkan peran orang tua dalam pendidikannya salah satunya untuk meningkatkan motivasi belajar, dan tingkat persepsi siswa tentang peran orang tua dalam pendidikan pada penelitian ini dapat mempengaruhi motivasi belajar siswa. Pengaruh dari orang tua sangat besar dalam membentuk kepribadian anak, untuk itu anak atau siswa membutuhkan dorongan dari orang tua khususnya dalam hal belajar (Slameto, 2010).

Hasil perhitungan analisis korelasi yang dilakukan diperoleh bahwa tingkat persepsi siswa tentang peran orang tua dalam pendidikan mempunyai korelasi yang positif terhadap motivasi belajar siswa, dari perhitungan korelasi didapat angka hubungan 0,48 merupakan hubungan pada kriteria cukup rendah, demikian juga dari perhitungan koefisien determinasi yang berfungsi mencari besarnya kontribusi variabel $\mathrm{X}$ terhadap variabel $\mathrm{Y}$, diperoleh hasil $\mathrm{KD}=23,04 \%$, atau kontribusi peran orang tua dalam pendidikan terhadap motivasi belajar siswa sebesar 23,04\% pada taraf kriteria kontribusi cukup rendah, dan sisanya 76,96\% oleh faktor lainnya. Bahwa motivasi yang berasal dari luar (ekstrinsik) yaitu dorongan yang datang dari luar diri (lingkungan), seperti dari orang tua, guru, teman-teman dan anggota masyarakat, (Dalyono, 2005). Berdasarkan uraian tersebut, dapat dikatakan tentang hubungan faktor-faktor tersebut terhadap motivasi belajar siswa. Orang tua adalah salah satu faktor eksternal yang berkaitan dengan motivasi belajar. 
Orang tua dapat membimbing untuk menumbuhkan atau membangkitkan motivasi belajar pada diri anak secara berkelanjutan sesuai dengan kondisi dan situasi anak pada saat-saat tertentu, melalui kesediaan orang tua untuk memotivasi anak, diharapkan anak tersebut memiliki kemandirian dalam belajar dan berupaya atau berinisiatif serta bertanggung jawab terhadap tugastugas belajarnya, karena apabila membiarkan anak tumbuh dan kembang tanpa peran orang tua, menjadikan anak tersebut sulit diatur dan sulit dikendalikan oleh orang tuanya, sehingga kelak akan mengalami hambatan dan kesulitan di masa depannya.

Hasil perhitungan hipotesis $\mathrm{p}-\mathrm{v}=-0,08<0,05$; dapat disimpulkan pada penelitian ini bahwa terdapat kontribusi yang positif dan signifikan tingkat persepsi siswa tentang peran orang tua dalam pendidikan terhadap motivasi belajar siswa pada mata pelajaran produktif. Sehingga orang tua mempunyai peranan penting dalam motivasi belajar anak/siswa. Orang tua memiliki peranan yang sangat penting dalam pendidikan anak-anaknya di antaranya sebagai motivator, (Slameto, 2010).

\section{KESIMPULAN}

Kesimpulan penelitian, yaitu tingkat persepsi siswa tentang peran orang tua dalam pendidikan, termasuk dalam kategori cukup rendah. Motivasi belajar pada mata pelajaran produktif siswa kelas XI TKR di SMKN 6 Bandung, termasuk dalam kategori baik. Tingkat

persepsi siswa tentang peran orang tua dalam pendidikan, berkontribusi terhadap motivasi belajar siswa pada mata pelajaran produktif dengan tingkat kategori kontribusi cukup rendah $(23,04 \%)$, dan sisanya $(76,96 \%)$ mendapatkan kontribusi dari faktor lain seperti guru, teman, dan lingkungan sosial siswa lainnya.

\section{DAFTAR PUSTAKA}

Dalyono, M. (2005). Psikologi Pendidikan. Jakarta: PT. Rineka Cipta

Hamalik, O. (2011). Proses Belajar Mengajar. Jakarta: Bumi Aksara.

Kurniadi. (2001). Mediator dalam Pengaruh Komunikasi Keluarga Terhadap Prestasi Belajar Anak [online], Vol 2. Tersedia: http://mediator.fikom.unisba.ac.id/index.php/mediator/ article/. [25 april 2013].

Nursito. (2002). Peningkatan Prestasi Sekolah Menengah. Jakarta: Insan Cendekia. 
Sardiman, A.M. (2010). Interaksi dan Motivasi Belajar Mengajar.Jakarta: PT. Rajagrafindo Persada.

Gunarsa, S.D. (1995). Psikologi Perkembangan Anak dan Remaja, Jakarta: PT. BPK Gunung Mulia.

Slameto. (2010). Belajar dan Faktor-faktor Yang Mempengaruhinya, Jakarta: Rineka Cipta.

Subroto, S. (1997). Proses Belajar Mengajar di Sekolah. Jakarta: Rineka Cipta.

Walgito, B. (2010). Pengantar Psikologi Umum. Yogyakarta: Andi. 